УДК 66.047-912

Орішкевич С.О. ${ }^{1}$, Собченко Г.О. ${ }^{2}$

${ }^{1}$ - Національний технічний університет Украйни «Київський політехнічний інститут»,

2 - Інститут газу НАН Украӥни, м. Київ.

\title{
МОДЕЛЮВАННЯ ПРОЦЕСУ ТЕРМООБРОБКИ ДРІБНОДИСПЕРСНИХ МАТЕРІАЛІВ В ІНЕРТНОМУ ПСЕВДОЗРІДЖЕНОМУ ШАРІ
}

У статті розглянуто особливості моделювання процесу термооборобки в інертному псевдозрідженому шарі дрібнодисперсного матеріалу.

В статье рассмотрены особенности моделирования процесса термообработки в инертном псевдоожиженном слое мелкодисперсного материала.

Modeling of the process heat treatment in an inert fluidized bed of fine material is showing in the article.

Застосування технології псевдозрідження для процесів термообробки дрібнодисперсних матеріалів розпочалось ще в середині минулого століття. Для певних видів процесів, таких як термообробка дисперсних матеріалів з розміром менше 1 мм та процесів спучування дрібнодисперсних матеріалів, доцільним є використання технології псевдозрідження в інертному шарі, яка є досить низьковитратною. Необхідним 3 точки зору реалізації технологічних процесів (проектування апаратного оформлення) $\epsilon$ дослідження процесів термообробки дрібнодисперсних матеріалів в інертному псевдозрідженому шарі як шляхом експериментальних досліджень, так і математичним моделюванням. Основні труднощі під час моделювання апаратів 3 інертним псевдозрідженим шаром пов'язані з тим, що розмір найбільших структур у ньому може досягати десятків міліметрів, тоді як розмір інших - декількох мікронів, тому розрахунок тепло-масообміних процесів ускладнюється. Сучасні математичні моделі дають можливість подолати проблеми, пов'язані зі складністю опису процесів, які відбуваються в апараті, але не дозволяють досягти певної точності. Тому створення математичних моделей для термообробки дрібнодисперсних матеріалів у псевдозрідженому інертному шарі є актуальною задачею.

Моделюванні інертного псевдозрідженого шару можна розглядати як окремий випадок псевдозрідженого шару. Основними моделями для опису руху частинок 
дрібнодисперсної фази в псевдозрідженому шарі є моделі ідеального змішування, кліткова і дифузійні моделі [1].

Для паралельно з'єднаних кліток однакового розміру, і за відсутності зворотного потоку, щільність розподілу часток дрібнодисперсного матеріалу за часом перебування в апараті визначається за залежністю

$$
\varphi(\tau)=\frac{\tau^{n_{\Omega}-1} \exp \left(-\tau /\left(\bar{\tau} / n_{\Omega}\right)\right)}{\left.\left(n_{\Omega}-1\right) !\left(\bar{\tau} n_{\Omega}\right)^{n_{\Omega}}\right)} .
$$

Для моделювання гідродинамічної картини псевдозрідженого шару використовують однопараметричні і двопараметричні дифузійні моделі $[1,2,3]$. Для апаратів з циліндричним корпусом використовують радіальну двопараметричну модель. При використанні однопараметричної дифузійної моделі приймається гідродинамічний режим для частинок матеріалу в вертикальному напрямку - ідеальне перемішування, а в горизонтальному напрямку спрямований рух із середньою швидкістю $v_{l}$ при наявності дифузійного перемішування часток.

Коефіцієнт дифузії дрібнодисперсного матеріалу можна розрахувати за рівнянням дисперсії часу перебування його в апараті, записаному в безрозмірних координатах [4]

$$
\sigma^{2}=2\left(\frac{D_{l}}{v_{l} L}-\frac{\left(D_{l}\right)^{2}}{\left(v_{l} L\right)^{2}}\left(1-\exp \left(-\frac{v_{l} L}{D_{l}}\right)\right)\right) .
$$

Для випадків, коли $\mathrm{Pe}=v_{l} L / D_{l}>10$ можна користуватися спрощеною залежністю $[2,4]$,

$$
\sigma^{2}=2 \frac{D_{l}}{v_{l} L}
$$

Ефективність використання однопараметричної дифузійної моделі для опису гідродинамічної картини псевдозрідженого шару була підтверджена результатами експериментальних досліджень [3, 5].

Крім розглянутих одно- i двопараметричних діфузійних моделей, для опису гідродинамічної обстановки в апараті процесу термообробки дрібнодисперсних матеріалів у псевдозрідженому шарі існують статистичні моделі.

Для моделювання руху газового потоку в інертному псевдозрідженому шарі можуть бути прийняті як модель ідеального змішування, так і модель ідеального витіснення, також можна використовувати перехідну модель (однопараметричну дифузійну). 
Для опису гідродинамічного режиму руху дрібнодисперсного матеріалу в інертному псевдозрідженому шарі найбільш прийнятні дифузійні і статистичні моделі, для моделювання гідродинаміки газового потоку - дифузійна модель.

При моделюванні кінетики процесу сушіння в інертному псевдозрідженому шарі дрібнодисперсних матеріалів не враховується градієнт температур і вологовмісту за об'ємом частинки $[1,6,7]$. Для періоду прогріву пропонується не враховувати зміну вологовмісту і обмежитися тільки розглядом теплового балансу $[1,7,8,9]$.

Для першого періоду сушіння швидкість процесу знаходять 3 рівняння для розрахунку коефіцієнта теплообміну $[1,6,8,10]$

$$
v_{v l 1}=\frac{K\left(t_{c}-t\right)}{r} .
$$

У період постійної швидкості сушіння кінетичні параметри процесу є функціями температури і вологовмісту матеріалу.

В якості розрахункової залежності для визначення швидкості процесу сушіння можна використовувати лінійну апроксимаційну залежність, отриману за значеннями поточного вологовмісту матеріалу (наближений метод Шервуда-Ликова) $[1,6,8,10]$

$$
v_{v l}=\frac{u-u_{p}}{u_{k r}-u_{p}} v_{v l 1} .
$$

При значній кривизні графічної залежності швидкості сушки від вологовмісту застосовується ступенева апроксимація для розрахунку кінетичних характеристик процесу [11].

$$
v_{v l}=\frac{\left(u-u_{p}\right)^{m}}{u_{k r}-u_{p}} v_{v l 1},
$$

яка при значенні $m=1$ ідентична методу Шервуда-Ликова.

Можливе уявлення кінетичних характеристик процесу сушки апроксимаційні залежністю вологовмісту матеріалу в часі [1]

$$
u=u_{0}-\frac{\tau}{A+B \tau},
$$

де $A$ і $B$ - константи, що залежать від теплофізичних властивостей матеріалу і режиму його сушіння.

Для матеріалів, які не мають достатньо вираженого періоду постійної швидкості сушки, але дають специфічну S-подібну криву процесу запропонована залежність [6, 12 , 13]

$$
v_{v l}=K_{c}\left(u_{0 p}-u\right)\left(u-u_{p}\right)
$$


де $K c$ - константа швидкості сушіння; $u_{0 p}$ - початковий рівноважний вологовміст після періоду прогріву при температурі мокрого термометра.

На швидкість процесу сушіння у другому періоді істотний вплив має енергія зв'язку вологи з матеріалом [8], визначення якої можна здійснити калориметричним методом [14] або по тиску пари над вільною поверхнею води [8].

Запропоновану математичну модель необхідно дослідити та перевірити.

В Інституті газу НАН України розроблено експериментальне обладнання для дослідження процесу термообробки (спучування) в інертному шарі, яке представлене на рис. $1[15]$.

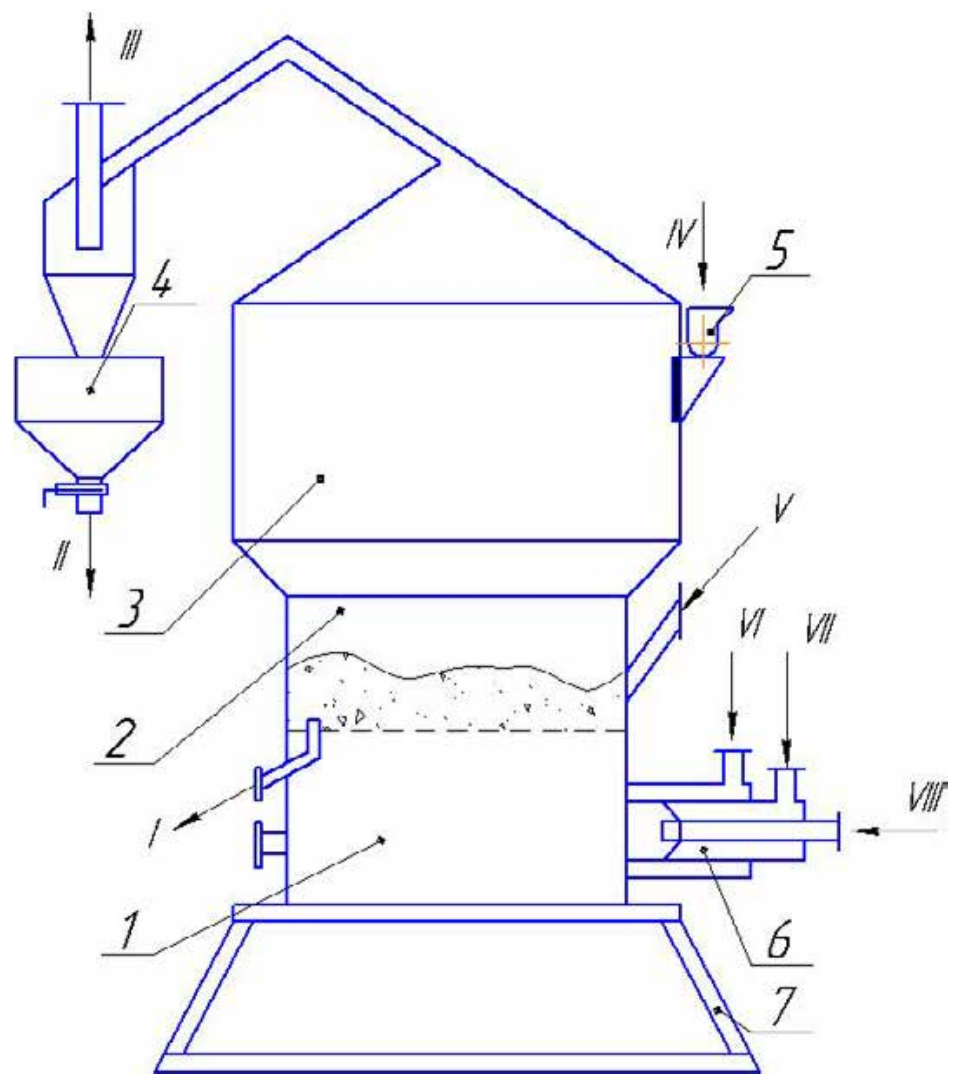

Рис. 1. Схема дослідної установки

1 - 3 топкова, робоча і сепараційна камери апарату з киплячим шаром відповідно; 4 - циклон з бункером готового продукту; 5 - живильник; 6 - газопальний пристрій; 7 підставка; I - аварійне вивантаження матеріалу киплячого шару; II - готовий продукт; III гази, що відходять; IV - вихідний матеріал; V - інертний зернистий теплоносій; VI вторинне повітря; VII - первинне повітря; VIII - природний газ. 
Для проведення лабораторних досліджень термообробки дрібнодисперсних матеріалів в інертному псевдозрідженому шарі в Інституті газу НАН України створена дослідна установка, конструкція якої схематично представлена на рис. 1.

Установка являє собою розбірну конструкцію і складається з топкової, робочої і сепараційної камер. Робоча і топкова камери розділені між собою безпровальною газорозподільною решіткою ковпачкового типу. Робоча камера має прямокутну форму 3 розмірами $0,15 \times 0,4$

На одній із торцевих стінок топкової камери розташовані газопальниковий пристрій типу СГ, на протилежній - оглядовий отвір, який є одночасно і люком для ручного розпалювання пальника. Над пальником в стінці сепараційної камери розміщено завантажувальний пристрій, що складається з власного механізму завантаження і мотора редуктора. 3 протилежного боку від пальника робочої камери розташоване розвантажувальний пристрій, що знаходиться на висоті 250 мм від рівня розподільної решітки.

Гази, що виділяються із сепараційної камери по газоходу, відводяться в циклон типу ЦН-15 для очищення і потім відкидаються в атмосферу. Вловлений в циклоні дрібнодисперсний матеріал збирається в бункері циклону, звідки періодично вивантажуються в якості готового продукту. Установка обладнана приладами контролю витрат природного газу та повітря, а так само температурного режиму.

Як матеріал для досліджень застосовані наступні вузькі фракції перліту 3 початковою вологістю $1 \%: 0,16 \ldots 0,4$ мм $\left(d_{\mathrm{e}}=0,22 \mathrm{мм}\right)$ - дрібна фракція; $1,0 \ldots 1,6 \mathrm{Mм}\left(d_{\mathrm{e}}=\right.$ $1,1 \mathrm{Mм})$ - середня фракція; 1,6...2,5мм $\left(d_{\mathrm{e}}=1,7 \mathrm{Mм}\right)$ - крупна фракція. Температурний діапазон досліджень $1100-1300{ }^{\circ} \mathrm{C}$. В якості інертного матеріалу використано корунд: $d_{\mathrm{e}}$ $=2,5 \mathrm{MM}$

Досліди проводились наступним чином. В інертний псевдозріджений шар, при його сталій температурі, вносилась проба досліджуваної фракції перліту, маса котрої істотно відрізнялась в меншу сторону від маси інертного шару; досліджувана проба перліту витримувалась протягом визначеного часу з підтримкою постійної температури шару, до спучування та винесення з шару; за допомогою аналітичних вагів визначена маса проби винесеного спученого перліту.

Порівнявши отримані експериментальні дані 3 результатами розрахунків математичного моделювання процесу спучування перліту в псевдозрідженому шарі 3 інертним матеріалом, одержали задовільні дані, що підтверджують можливість використання математичної моделі. 


\section{Перелік посилань}

1. Фролов В.Ф. Моделирование сушки дисперсных материалов/ В.Ф. Фролов. - Л.: Химия, 1987. - 208 с.

2. Кафаров В.В. Методы кибернетики в химии и химической технологии/ В.В. Кафаров. - М. : Химия, 1971. - 496 с.

3. Павлов А.С. Оценка режима движения дисперсной фазы в проточном аппарате с виброожиженным слоем/ А.С. Павлов, В.Е Бабенко// Химическая промышленность. 1982. - №10. - C. 45-46.

4. Кафаров В.В. Математическое моделирование основных процессов химических производств / В.В. Кафаров, М.Б. Глебов. - М. : Высшая школа, 1991. - 400 с.

5. Земскова В.Т. Математическое описание процесса сушки дисперсных материалов в сушилке виброкипящего слоя с направленным перемещением материала / В.Т. Земскова, Н.Н. Барабанов, В.Ф. Фролов// Изв. Вузов.: Химия и химическая технология. - 1984. - Т. 27 - Вып. 1. - С. 104 - 108.

6. Сажин Б.С. Научные основы техники сушки / Б.С. Сажин, В.Б. Сажин. - М. : Наука, 1997. -448 c.

7. Харин В.М. Кинетика сушки во взвешенном слое/ В.М. Харин, Ю.И. Шишацкий// TOXT. - 1995. - T. 29, №2. - C. $179-186$.

8. Лыков А.В. Теория сушки / А.В. Лыков. - 2-е изд. - М. : Энергия, 1968. - 471 с.

9. Лыков М.В. Сушка в химической промышленности/ М.В. Лыков. - М. : Химия. 1970. $-432 \mathrm{c}$.

10. Путилов К.А. Термодинамика / К.А. Путилов. - М. : Наука, 1971. - 376 с.

11. Исследование гидродинамики при сушке полимерных материалов в виброкипящем слое/ В.И. Муштаев, Б.М. Коротков, В.А. Чевиленко и др. // Химическое и нефтяное машиностроение. - 1973. - №12. - С. 13-14.

12. Фролов В.Ф. Лекции по курсу ПАХТ/ В.Ф. Фролов. - СПб. : Химиздат, 2003. - 608 c.

13. Моделирование и расчёт процесса сушки термолабильных материалов в виброаэрокипящем слое: монография / А.И. Леонтьева, К.В. Брянкин, А.А. Дегтярев, В.С. Орехов. - Тамбов: ГОУ ВПО ТГТУ, 2011. - 80 с. - 50 экз. - ISBN 978-5-8265-0973-9.

14. Хеммингер В. Калориметрия. Теория и практика / В. Хеммингер, Г. Хене. - М. : Химия, 1990. - 176 с.

15. Хвастухин Ю.И. Сушка и дегидратация фосфогипса в слое инертного зернистого теплоносителя/ Хвастухин Ю.И., Когута Н.К., Роман С.Н., Нульман О.Н., Руденко В.В.// Экотехнологии и ресурсосбережение №1, 1998. 